The digital transformation of microfinance institutions: An empirical analysis

\begin{tabular}{|r|l|}
\hline Journal: & Journal of Applied Accounting Research \\
\hline Manuscript ID & JAAR-02-2021-0041.R3 \\
\hline Manuscript Type: & Research Paper \\
\hline Keywords: & $\begin{array}{l}\text { Microfinance institutions, Fintech, Accounting data, Social performance, } \\
\text { Digitization, Digital solutions }\end{array}$ \\
\hline
\end{tabular}




\section{The digital transformation of microfinance institutions: An empirical analysis}

August 13, 2021 
- Purpose digital transformation of microfinance institutions (MFIs).

- Design/methodology/approach

The study employs probit models to investigate the likelihood of integrating digital solutions by MFIs and Heckman models for robustness checks.

- Findings

The findings reveal that the adoption of these tools is consistent with the social performance of MFIs. Furthermore, the profitability of the institutions and their home country development are associated with a larger application of digital support solutions.

- Practical implication

The results imply that the adoption of digital solutions does not necessarily harm the social performance of MFIs. In addition, the findings may imply that financial sustainability can serve as being a preliminary condition but must not lead to the mission drift of MFIs. Findings of the study have implications for policy makers, donors and investors who wish to accelerate the digital transformation within the microfinance industry and to significantly boost financial inclusion. A focus on more social-oriented MFIs can be an appropriate solution. Furthermore, the pathway to digital financial inclusion through microfinance can be made more efficient if improved and supportive facilities as well as systems for digital technology are available.

- Originality/value

This paper is the first one which highlights the relationship between the MFI's social performance and the application of digital solutions by MFIs. Furthermore, we discuss this link while considering cost aspects. - Research limitation/implication

Since the survey data collected is not longitudinal and does not cover many MFIs, it may encounter the absence of comprehensive results. Moreover, the study is limited to supply-side incentive factors, thus lacks of investigations under supply-demand interaction schemes. Therefore, future studies are encouraged to fill up these knowledge gaps.

Keywords: Microfinance institutions, Fintech, Digital solutions, Social performance, Digitization 


\section{Introduction}

In 2015, the United Nations General Assembly emphasized the importance of sustainable development through the introduction of a plan of action, named "Transforming our World: The 2030 Agenda for Sustainable Development". The Agenda comprises 17 Sustainable Development Goals (SDGs) aimed at paving the way for the improvement of people's lives in United Nations member countries. Although the term financial inclusion is not explicitly cited in the statement of United Nation's 17 SDGs, it has been considered to play a pivotal role in attaining several targets through this, for example combating poverty, improving living standards, and promoting economic growth (Ma'ruf and Aryani, 2019; Fu et al., 2017). In other words, SDGs may only be achieved through some support of an inclusive financial system. Therefore, financial inclusion has been placed in a priority position in the development agenda of many countries (World Bank, 2018; Arun and Kamath, 2015). Although the financial inclusion concept is expressed differently in words (World Bank, 2018; UNCDF, 2017; UNSGSA, 2018), it generally refers to the affordable and sustainable access and use of appropriate financial services for all sections of the population. Its ultimate goal is to create better opportunities and environment for finance.

However, low-income individuals may find it hard to overcome several barriers in order to access to formal financial systems, especially the banking system, due to their lack of collateral or low level of credit-worthiness. As noted by Demirgüç-Kunt et al. (2018), the financing gap remains severe with approximately 1.7 billion adults in possession of neither a financial institution nor mobile money account, which the poor mainly comprises. The difference in terms of account ownership by gender remains significant, with formal accounts of men accounting for $9 \%$ more than those of women in developing countries. Additionally, data from their study shows that $47 \%$ of survey participants borrowed money in 2017 but only $11 \%$ of these borrowed from financial institutions. Moreover, credit supply to small and microenterprises met less than half of the potential needs in the developing countries, compared with the financial demand of 8.9 trillion US Dollars (Bruhn et al., 2017). Thus, there is a great potential for the microfinance sector to support the goal of financial inclusion. Several theoretical and empirical studies demonstrate the linkage between microfinance and financial inclusion (Mushtaq and Bruneau, 2019; Mader, 2018; Brown et al., 2016). 
Given the social importance of financial inclusion and the MFI's need of moving towards sustainable development, an investment in financial technology, i.e. digital finance, is considered as an appropriate strategy in connection with the MFI's corporate social responsibility (CSR) strategy and business model (Ashta, 2018). Digital finance, which is defined as being the application of digital tools (solutions) for finance, not only promotes better customer services but also encourages the effective operational management of MFIs. Only a few decades ago, access to digital financial services, mobile banking or electronic payments appeared to be impossible. Ritchie (2017) summarizes data on the global trend toward adopting the technology until 2017. The study shows impressive shreds of evidence on the explosion of mobile phone and mobile money account adoption. While digital technology used to be viewed as a comparatively expensive approach toward finance as a whole, expecting the financially excluded population to adopt digital tools and services appeared to some extent to be unrealistic and unfeasible, mainly with respect to financial affordability. Yet with the rapid revolution of digital technology and modern smart devices, digital finance has emerged as a new way of delivering financial services and products efficiently and effectively. The recent years have seen a dramatic change in not only policymakers' and financial institutions' attention, but also in customers' perception towards digital finance (Pazarbasioglu et al., 2020). For example, M-PESA is one of the most famous and successful experiences of integrating new fintech apps to payment and lending services, which highlights the effort of delivering financial services to the formally unbanked population (Van Hove and Dubus, 2019). Furthermore, the role of digital solutions in financial inclusion is seen indirectly through the positive impacts on institutions' operational management. By incorporating digital tools into the business process, financial service providers can better manage risk and cost-related problems as well as thoroughly analyze customer data and information (Wyman, 2017; Pytkowska and Korynski, 2017).

Considered in its entirety, moving toward digital tools, when implemented effectively and sustainably within the framework of appropriate regulation, appears to be one of the important drivers for promoting not only faster progress but also an efficient method toward attaining financial inclusion (Yeow et al., 2017; Ghani et al., 2018; Vong and Song, 2015). Thus, exploring the determinations of digital supporting solutions adoption is needed in order to promote their diffusion. However, in contrast to the demand side, research 
on supply-side drivers, i.e. from financial service providers side, seem to be lagged behind. Additionally, while there is a vast amount of literature which focus on digital transformation in the banking system (Mbama and Ezepue, 2018; Shaikh et al., 2017; Jünger and Mietzner, 2020), little is known about the underlying reasons that motivate MFIs toward their position within the application of digital tools.

This paper is one of the first empirical ones to shed light on the digital solutions adoption of MFIs. The discussion in the current study contributes to the exploration of several factors that link with the application of digital solutions by MFIs. Using a data set from a worldwide MFIs survey on IT solutions and Rural lending, which was conducted by YAPU Solutions, we test whether MFIs' digital software adoption is related to MFI-specific characteristics and macroeconomic factors. To be more specific, we examine whether there is a relationship between the social mission of an MFI and its decision to adopt digital tools. Furthermore, we investigate whether or not the profitability of MFIs, measured by return on equity, is related to an MFI's digital solutions application. Finally, we explore to which extent the economic development of the country in which an MFI is located is related to the adoption of digital solutions of MFIs. The key findings of our article show that the use of digital solutions is related to economic development, an MFI's profitability, and social performance.

The remainder of this paper is structured as follows: Section 2 highlights the importance of digital solutions to microfinance in deepening financial inclusion, identifies related and recent literature on the application of digital, and builds on the hypotheses. Section 3 presents the data source and methodology used to investigate the proposed statements. The empirical examinations and results are then explored in section 4. Finally, section 5 briefly summarizes the findings and discusses some potential future work. 


\section{Theoretical background and hypotheses}

\subsection{Literature review on microfinance digital adoption and social performance}

MFIs are considered to have orientation on social responsibilities which are beyond making financial benefits (Hudon and Sandberg, 2013; Mersland and Strøm, 2010). Their primary intention is to serve the poor and unbanked with small loans, which are frequently neglected by traditional banking systems. The banking system might want to address their CSR towards these disadvantaged groups; however, providing such small loans with high transaction costs goes against their business concept. Furthermore, under asymmetric information, the problem of credit rationing can further make the poor find it hard to access financial services. The existing body of literature has deeply explored the social performance of MFIs. While there are an extensive number of studies devoted to the measurement of social performance (D'Espallier and Goedecke, 2019; Beisland et al., 2020), the trade-off between social and financial goals within MFIs provokes a heated debate and attracts the attention of a large number of scholars and other stakeholders (Mersland and Strøm, 2010; Dorfleitner et al., 2019). Academic research has also highlighted considerable concerns towards the impacts and driving factors of social performance (Hermes et al., 2011; Dorfleitner et al., 2017a). Furthermore, social responsibility initiatives of MFIs in connection with CSR strategy have been documented by a number of academic papers (Allet and Hudon, 2015; Chakrabarty and Bass, 2015; Okoe and Boateng, 2016). Based on the literature, it can be stated that the MFI's social responsibilities, which represent CSR strategy, are important and should be addressed appropriately. However, performing social responsibility through bringing financial services to the vulnerable groups in the population is evidently a costly business process (D'Espallier et al., 2013; Cull et al., 2018). Over the past decades, MFIs have been struggling with finding and applying alternative business models to reduce costs, accelerating greater outreach to remote areas, and quickly and efficiently meeting customer financial requirements (Labie et al., 2011). Mersland and Strøm (2012a) illustrate that while struggling with the management of high costs and low returns in delivering services to the poor, the social performance of MFIs can remain unchanged. Therefore, MFIs that address CSR need to tackle these issues. 
In response to these challenges, especially during the explosive digital era, digital applications and other smart devices such as smartphones or tablets have been increasingly deployed by MFIs to digitize core business operations, such as loan disbursement. Information and communication technology (ICT) is illustrated as being one of the key pillars in the microfinance innovation process toward becoming more mature and surviving in an increasingly competitive environment (Kauffman and Riggins, 2012). The authors argue that ICT is not only an important tool for the business operation of MFIs, but also a motivation that forces a more competitive environment in the microfinance industry. Moreover, Vong and Song (2015) illustrate that mobile service solutions do have positive impacts on lowering transaction and administration costs of MFIs, which subsequently helps to reduce the lending rate. From this perspective, both MFIs and their borrowers benefit from the application of mobile technology. Pytkowska and Korynski (2017), in their survey-based research, point out that even if MFIs are not fully digitized, digital solutions have shown themselves to be helpful in some aspects of their business processes. Otherwise, they would lose their competitiveness to other digital credit providers, for example, mobile banking providers and lending platforms. Yet, in the vast majority of MFIs, the existence of digital solutions varies considerably. For example, MFIs in South Asia and Latin America and the Caribbean tend to use more innovative mobile technology in delivering financial services than their peers in other regions (Dorfleitner et al., 2019). The possible explanation is the significant and fast growth of mobile technology in these regions. Thus, the differences in the MFI's digital solution adoption need to be considered more intensively.

\subsection{Hypotheses development}

To build a sound theoretical framework from which we can derive some testable hypotheses, we start with a basic equation for the profit $P$ of an MFI (Dorfleitner et al., 2020), namely

$$
P=I-F E-L L-O E,
$$

where $I$ represents the interest income (including fees), $F E$ the financial expenses, $L L$ the loan losses and $O E$ the operating expenses. 
Although digital solutions have proven to bring several benefits to financial institutions such as a better delivery of financial services and cost efficiency (Ivatury, 2009, Lee et al., 2021), it cannot be denied that the high upfront cost of digital technology can be burdensome to many of them. To be more specific, the process of integrating digital financial solutions frequently requires a high amount of financial investment for planning, adapting the current systems, and finding specialized experts to operate the new technology. MFIs are not exempt from this phenomenon. Therefore, sufficient financial resources are necessary for them to tackle this problem. It is well-known that the yield from the gross loan portfolios is the main source of revenues as well as finance of MFIs. To implement digital solutions, an MFI requires sufficient financial support, which could come from the institution's profits. This is a first indication that those MFIs which exhibit a high level of profitability could be more likely to employ digital solutions. To reach high profitability, MFIs may either increase the interest rate or increase the size of their loan portfolio or decrease their expenses.

Equation (1) provides more insights. On the one hand, transaction cost theory posits that an institution's economic efficiency is driven by economizing costs related to transactions such as monitoring, controlling and managing (Williamson, 1979). In the microfinance industry, the operating expense has been found to be a crucial determinant of MFI's lending rate (Dorfleitner et al., 2013). The existing body of literature has shown that social-oriented MFIs tend to exhibit high operating costs (Meyer, 2019), while cost-efficiency should be one of the concerns of these institutions (Mersland and Strøm, 2010). To tackle this problem, digital solutions can play an important role as a remedy to bring down the operating expense. Digital technology is perceived to support organizations in managing their operations and business model, which subsequently can lead to more cost-efficiency. As the costs related to the process, management and control of lending loans are relatively fixed (per loan), the average operating cost per loan lowers with the decrease of average fixed costs. Indeed, Dorfleitner et al. (2019) find a negative relationship between operating expenses and the adoption of mobile financial services, which are one special kind of digital financial services.

On the other hand, asymmetric information risks in the form of moral hazard and adverse selection, which is demonstrated in Stiglitz and Weiss (1981, 1983), triggers severe problems in the credit market. Microfinance literature has also mentioned these issues in explaining the probability of default 
(McIntosh and Wydick, 2005; Dorfleitner and Oswald, 2016), which materializes in form of the variable $L L$ in the equation. The major consensus is that asymmetric information risks pose detrimental effects on the probability of repayment and increase the loan loss rate of MFIs. Financial technologies, such as digital credit scoring or cloud-based loan tracking systems, prove to accelerate information sharing and acquisition (Benami and Carter, 2021). Thus, MFIs can effectively manage their loan contracts and reduce the incidents of loan loss, which subsequently increases their profit.

Furthermore, obviously the interest revenue $I$ is positively related to the number of loans, the charged interest rate and the average loan size. In terms of profitability, digital solutions can help to increase the number of loans along with a disproportionately low increase of $O E$. Besides the pure financial aspects, the interest revenue also is associated with the social mission. Those MFIs with a high CSR might not want to raise the interest rate or rely heavily on large-sized loans as this could negatively impact their customers. To this end, digital solutions can also be utilized to provide more loans without having to increase the loan size or the interest rate, which in turn is an argument for a positive relation between social performance and digital solutions.

More support for our argumentation can be derived from further empirical literature. For instance, Amersdorffer et al. (2015) point out the importance of financial self-sufficiency to balance social objectives. The authors provide evidence in the case of Bulgarian agricultural credit cooperative and show that only financially well-managed MFIs manifest a better social output. This view is also examined by Beisland et al. (2020), who evidence that the strong balance between the social and financial performance of MFIs can yield a higher social rating. Several other studies find well-managed, cost-efficient MFIs to have a better social performance, as positive changes in profitability and financial sustainability could result from improved governance and financial management (Mersland and Strøm, 2009, 2012b; Ayayi and Sene, 2010; Iqbal et al., 2019). Moreoever, Dorfleitner et al. (2019) provide proof that social performance (measured by average loan size) is positively associated with the MFI's provision of mobile financial services. This suggests that digitization and social missions can harmonize. The existing body of literature also highlights the positive relationship between the application of digital solutions and the managerial capability of financial institutions (Moro Visconti and Quirici, 2014; Mora and Prior, 2018). Therefore, integrating digital 
solutions into the business model proves to be a promising solution to solve the cost-related problems, which subsequently enables a higher level of profitability as well as lower interest rates. Building on the literature, one can expect that MFIs that are proficient at operational management will exhibit better social performance and adoption of digital solutions. Furthermore, digital technologies play a pivotal role in closing the gender gap with regard to financial inclusion (Sioson and Kim, 2019). Thus, MFIs that focus on female borrowers could also tend to be associated with the implementation digital solutions.

To measure the social performance of MFIs, several concepts are introduced in the literature. The percentage of female borrowers has been utilized as a proxy for the social performance of MFIs in several previous articles (Dorfleitner et al., 2017b; D'Espallier et al., 2013; Hermes et al., 2011). According to Morduch (1999) and D'Espallier et al. (2013), female borrowers have traditionally been perceived to constitute a large percentage of clients for the majority of MFIs. Academic research has also shown that women clients are associated with small loans, which require more effort and cost from MFIs in terms of management (Hermes et al., 2011; D'Espallier et al., 2013). According to the fixed-costs-per-loan argument in the theoretical part, the costs of organizing, processing and monitoring are frequently relatively high for small loans. Thus, MFIs striving for social objectives by focusing on lending to women are more likely to encounter the cost-efficiency problem. Another frequently employed measure for the social performance of MFIs in the existing literature is the average loan balance (Hermes et al., 2011; Dorfleitner et al. 2019), which is interpreted as follows: the lower this value, the poorer the customers are. Thus, social-oriented MFIs, which lend more to the poor, can suffer the problem of high transaction cost in providing loans of small sums. As argued above, with digitization MFIs can more easily offer smaller loans without sacrificing profitability.

Summarizing this discussion, we propose the following two hypotheses.

Hypothesis 1 (H1). The social performance of an MFI is positively related to the likelihood of the adoption of digital solutions.

Hypothesis $\mathbf{2}(\mathrm{H}[2)$. The profitability of an MFI is positively related to the likelihood of the adoption of digital solutions.

Note that when postulating these two hypotheses, we do not intend to refer to causal relationships, which becomes apparent from the above discussion. 
The arguments rather express that the MFI's better and more efficient management capabilities may foster digitization in order to achieve a better financial and social performance. The lack of causal hypotheses should not be a limitation of this research as our focus is to characterize the MFIs adopting digital solutions by utilizing correlation analysis.

In addition to MFI-specific characteristics, country-specific and societal influences should be considered to explain differences between the MFIs' digital solutions adoption. As shown by Cámara (2018), the level of digitization, which is measured by DiGiX index, is more likely higher in the developed economies than their developing counterparts. Even though digital solutions can positively impact the financial value chain activities (Pytkowska and Korynski, 2017), the integration of these tools requires the presence of sufficient and stable infrastructure. Parada and Bull (2018) also argue that the insufficiency and instability of infrastructures is one of the main reasons that hinders the ability to adopt digital tools in Africa. As highlighted by Kumar et al. (2010), many MFIs realize the importance of digitalization and show their willingness to introduce new technology, i.e. mobile banking, but one of the largest obstacles is the availability of the related infrastructure. Later on, Ketterer (2017) also argues that insufficient infrastructure can lead to the unwillingness in implementing digital finance due to the lack of connectivity. This, however, appears to be notably prevalent in less developed countries (Hinson et al., 2019). Furthermore, literature has shown that organizations in more developed countries tend to engage more in CSR (Ali et al., 2017; Bhatia and Makkar, 2019) and that digital technology addresses the firm's social challenges (George et al., 2020). Greater awareness of the competitiveness of digitization is also observed within MFIs located in more developed countries (Pytkowska and Korynski, 2017). Thus, it is reasonable to put forward the idea that digital innovation can be utilized more by MFIs in developed economies as a means of CSR. From the above-mentioned discussions, we conclude that MFIs in developed countries may be more likely to adopt digital solutions because of their CSR advocate and the availability of a supportive environment. Therefore, we propose the following hypothesis: Hypothesis 3 (H[3). The economic development of a country is positively related to the likelihood of the adoption of digital solutions by MFIs. 


\section{Data and methodology}

\subsection{Description of data and variables}

In late 2017, an online survey which was conducted by YAPU Solutions, a social fintech company, aimed at supporting financial institutions through software services, was sent to microfinance institutions in various regions globally. The questionnaire was dedicated to the use of IT solutions and rural lending by MFIs and prepared using the Monkey survey platform. The email with the link to the online survey was then distributed to MFIs initially in November 2017, and was then followed by three reminder emails. By March 2018, the survey had finally been completed. The questionnaire was written in the three most frequently spoken languages, namely English, Spanish, and French, to acquire more interest and more responses from the surveyed institutions. Several topics of interest were included in the survey, such as the use of digital solutions, the perception toward rural and agriculture finance, renewable energy and energy efficiency lending. Questions related to the adoption of digital solutions were presented at the top of the survey. After careful consideration, the number of consistent and reliable responses to the survey is 150 MFIs. However, due to the availability of the institutions' specific information obtainable from MIX Market database, we are only able to utilize 105 questionnaires.

Mix Market database has been used as an important public source of data regarding the profile information and financial performance of MFIs for many studies in the microfinance field due to its transparency and availability of a large amount of data (Dorfleitner et al., 2017b; D'Espallier et al., 2013; Allet and Hudon, 2015, e.g.). This institutional database can be used to track several finance- and accounting-related activities since it encompasses data on assets, liabilities, revenues, costs, income, employees, end customers and types of financial products. In 2015, there were over 1000 MFIs that reported their annual financial performance data to MIX Market. From these, we selected only those MFIs with realistic and consistent data, the reason being that MFIs voluntarily publicize their financial performance data and profile information to MIX Market. These reports often lack official authorized audits, which in turn feasibly causes several unrealistic and contradictory values to be viewed with caution. 
To tackle these problems, we exclude MFIs with the following criteria: percentage of female borrowers greater than $100 \%$, gross loan portfolio smaller than zero, or portfolio at risk larger than one, as for all three variables such values are impossible and thus obviously erroneous. Further, we follow (Dorfleitner et al., 2019) and (Dorfleitner et al., 2020) and exclude MFIs with an average loan balance per borrower greater than 15,000 US Dollars, as such a high average value indicates a lack of focusing on microloans. Moreover, still in line with the mentioned references, we exclude observations with a return on assets ratio less than 1.5 or a nominal yield on gross loan portfolio greater than one, as such values are regarded to be unrealistic.

Note that our empirical estimation, with Digital as a binary dependent variable, is not intended for the study of the causality between the application of digital solutions and an MFI's performance, but rather to identifying characteristics of MFIs' integration of digital solutions. Therefore, following (Dorfleitner et al., 2019), lagged values for MFI-specific variables are employed. We then merge our two adjusted data sets with macroeconomic data from World Development Indicators and the G20 Financial Inclusion Indicators database, which are both sourced from the World Bank data platform. The resulting sample contains 984 MFIs which reported information to MIX Market in 2015, 105 of which responded to the survey.

Detailed descriptions of the variables used in the study are presented in Table 1. Our dependent variable is the use of digital solutions Digital. We define Digital as being the use of any digital software that contributes to the support of various aspects of an MFI's operation, such as data collection and/or analysis, risk assessment, loan disbursement and/or monitoring. Dedicated software solutions used by MFIs could be, inter alia, specialized desktop software or software/Apps for tablets or smartphones. In the context of this study, spreadsheet software is not treated as a digital tool in helping to define the concept of modern movement towards digitalization. Our dependent variable of interest is a binary variable that takes the value of 1 if MFIs do apply digital solutions to their operational business activities and otherwise 0 .

The MFI-specific explanatory variables indicate factors linked to the social performance and the profitability of the MFIs. In the existing body of literature on the social performance of MFIs, the poverty of the customers is measured through average loan balance because the smaller the average loan 
amount lending to customers, the poorer they are. Moreover, women are frequently treated as being more financially vulnerable than men. Therefore, a high ratio of female borrowers implies a deep outreach of an MFI, i.e., better social performance. Thus, the percentage of female borrowers and average loan balance per borrower divided by GNI per capita (ALBGNI) are employed to measure MFI social performance (see, for example, Dorfleitner et al. (2017a), D'Espallier et al. (2013)). Although ESG indicators would be a promising proxy for social performance, we cannot employ such metrics in this paper ${ }^{1}$ MFI profitability, which is represented by the return-on-equity ratio, measures the ability to generate the profits of MFIs in comparison with shareholder equity, with the intuition being the higher the better. $R O E$ has been a traditional proxy for profitability in previous studies (Abrar et al., 2016; D'Espallier et al., 2017). The GDP per capita is employed to represent the impact of macroeconomic factors.

We use MFI donations, write-off ratio ( WOR), and percentage of rural loans (Rural) as MFI-specific control variables. The Donations dummy takes the value of 1 if the MFIs receive donations in the reference year and 0 otherwise. WOR measures the proportion of loans that have been written off, which is divided by the average gross loan portfolio. Finally, the variable Rural is included to reflect the expectation that the greater the concentration on rural lending, the more interest in digital tools. The legal status of MFIs can also influence the decision to adopt digital solutions. Therefore, a set of dummy variables is included to manage the effect of the type of MFIs. In particular, there are four different groups of the legal status of MFIs, including Credit Union/Cooperative; Non-bank financial institutions (NBFI); Non-government organizations (NGO), and the reference category Bank and others.

As additional explanatory variables, we further include two macroeconomic variables, namely the domestic credit distributed by the financial sector as a percentage of GDP (DOMCRE) and dispute resolution index, reflecting the existence of dispute resolution mechanisms in the country (Dispute) in the selection equation (see detailed definition in Table 1). According to Doumbia (2016), the economic growth of a country is consistent with the development

\footnotetext{
${ }^{1}$ Our main source of MFI-level data comes from the MIX Market database, which is the largest public data set. However, it does not contain information on the ESG performance of MFIs. ESG indicators can be easily obtained for publicly listed companies, while there are very few MFIs fulfilling this property.
} 
of the financial sector measured by the domestic credit by the financial sector as a percentage of GDP. In addition, Kriese et al. (2019) show the positive influence of dispute resolution mechanisms on the level of economic development. Thus, it can be argued that the level of domestic credit by the financial sector and dispute resolution mechanisms are indicators of the economic growth of a country. Moreover, we expect MFIs with a higher level of transparency to be more likely to disclose their viewpoint to our survey. Therefore, the variable Diamonds, which represent the MIX Market rating score on MFIs' reports, is employed with three categories (Unrated, Low, and High).

\subsection{Methodology}

As previously stated, our dependent variable, Digital is a binary variable that takes two values, namely 0 and 1 . Therefore, we run several probit regressions with Eicker - Huber - White heteroskedastic - consistent standard errors in order to estimate the effects of the social performance, the profitability of the institution, and the level of the economic development of the country. The following regression model is estimated:

$$
\begin{gathered}
y_{i}^{*}=\alpha+\beta_{1} x_{i}+\beta_{2} c_{i}+\epsilon \\
y_{i}= \begin{cases}1, & \text { if } y_{i}^{*}>0 \\
0, & \text { if } y_{i}^{*} \leq 0\end{cases}
\end{gathered}
$$

where $y_{i}^{*}$ is the latent continuous variable reflecting the use of digital solutions by MFIs $i$. Meanwhile, $y_{i}$ is an observed dummy variable referring to the adoption of digital solutions. It takes the value of 1 if an MFI employs digital tools and 0 otherwise. While $\beta_{1}$ refers to the coefficient of the hypothesis-related variables, the vector of variables, $x_{i}$, consists of four independent variables (see Table 1). A vector of control variables is denoted by $c_{i}$ with $\beta_{2}$ representing the coefficient for this vector, while $\epsilon$ is the error term for the model. One of the limitations of our data set is the self-declaration of the MFIs to MIX Market, which can lead to the problem of missing values for several variables. For the reason that the number of MFIs who responded 


\begin{tabular}{|c|c|}
\hline Variable & Description \\
\hline Digital & $\begin{array}{l}\text { Dummy variable indicates whether MFI uses IT solutions or not (exempt excel). } \\
\text { If yes, it takes the value of } 1 \text { and otherwise } 0 \text {. IT solutions are: Specialized } \\
\text { desktop software; Software/App for tablets or smartphones in the field; Tablets } \\
\text { in the field, Smartphones in the field by MFIs. }\end{array}$ \\
\hline Apps & $\begin{array}{l}\text { Dummy variable indicates whether MFI uses the following digital solutions or } \\
\text { not: Software/App for tablets or smartphones in the field; Tablets in the field, } \\
\text { Smartphones in the field by MFIs. If yes, it takes the value of } 1 \text { and otherwise } \\
0 .\end{array}$ \\
\hline Software & $\begin{array}{l}\text { Dummy variable indicates whether MFI uses Software/App for tablets or smart- } \\
\text { phones in the field or not. If yes, it takes the value of } 1 \text { and otherwise } 0 .\end{array}$ \\
\hline Answer & $\begin{array}{l}\text { Dummy variable refers to the response status of MFIs. It takes the value of } 1 \text { if } \\
\text { MFIs replied to the survey. Otherwise, it equals } 0 .\end{array}$ \\
\hline Age & $\begin{array}{l}\text { Indicator for the number of years institution has functioned as an MFI, as of } \\
2017 \text {. }\end{array}$ \\
\hline Assets $(\ln )$ & Logarithm of total assets. \\
\hline DTE & Indicator for debt to equity ratio. \\
\hline Yield (r) & Indicator for yield of gross portfolio (real). \\
\hline ROE & Indicator for return on equity. \\
\hline OEA & Indicator for operating expense to total assets. \\
\hline ALBGNI & $\begin{array}{l}\text { Indicator for average loan balance, obtained by dividing average loan balance } \\
\text { per borrower by gross national income per capita (GNI). }\end{array}$ \\
\hline Female & Indicator for the percentage of female borrowers. \\
\hline GDPpc & Logarithm of gross domestic products per capita of the country in which the \\
\hline WOR & Indicator for write-off ratio. \\
\hline PAR30 & $\begin{array}{l}\text { Indicator for portfolio at risk over } 30 \text { days, calculated by dividing sum of out- } \\
\text { standing balance, portfolio overdue } 30 \text { days and renegotiated portfolio to gross } \\
\text { loan portfolio. }\end{array}$ \\
\hline Rural & Indicator for the proportion of number of rural loans. \\
\hline Donations & $\begin{array}{l}\text { Dummy variable that indicates whether or not the MFI received donations in } \\
\text { the year observed. It takes the value of } 1 \text { if the MFI obtained donations and } \\
\text { otherwise } 0 .\end{array}$ \\
\hline DOMCRE & $\begin{array}{l}\text { Indicator for domestic credit by the financial sector as percentage of GDP of the } \\
\text { country where MFI is located. }\end{array}$ \\
\hline Dispute & $\begin{array}{l}\text { Indicator for the dispute resolution index reflecting the existence of formal inter- } \\
\text { nal and external dispute resolution mechanisms. (1) Internal mechanism indica- } \\
\text { tor: law or regulation setting standards for complaints resolution and handling } \\
\text { by financial institutions. (2) External mechanism indicator: System in place that } \\
\text { allows a customer to seek affordable and efficient recourse with a third party. }\end{array}$ \\
\hline Diamonds & $\begin{array}{l}\text { Rating score of MFIs defined by MIX. It is categorized into } 3 \text { groups, namely Un- } \\
\text { rated (not ranked yet), Low (MFIs are ranked } 1-3 \text { diamonds), and High (ranked } \\
4-5 \text { diamonds). The reference category is Unrated. }\end{array}$ \\
\hline Region & $\begin{array}{l}\text { Categorical variable for the geographical location of the MFI. The regions are } \\
\text { Africa and the Middle East and North Africa (MENA), East Asia and the Pa- } \\
\text { cific (EAP), Eastern Europe and Central Asia (EECA), Latin America and the } \\
\text { Caribbean (LAC), and South Asia. The reference category is Africa and MENA. }\end{array}$ \\
\hline Type & $\begin{array}{l}\text { Categorical variable for the legal status of MFIs. There are MFIs of the type } \\
\text { Bank and Others, Credit Union/Cooperative, Non-bank financial institutions } \\
\text { (NBFI), and Non-government organizations (NGO). The reference category is } \\
\text { Bank and Others. }\end{array}$ \\
\hline
\end{tabular}

Note: Sources of data

Variables "Digital" is derived from the survey on Rural Lending and IT Solutions.

Data for GDPpc and the variable "DOMCRE" are collected from the World Development Indicators.

Data for the variable "Dispute" is collected from G20 Financial Inclusion Indicators.

Data for all other variables are collected from the MIX Market database. 
to the survey is already very limited, mean imputation is employed as a technique to overcome the problem of missing values, i.e, the mean of observed values of one variable is used to replace all the missing values of said variable.

The problem of bias due to sample selection may exist because of the inability to obtain a perfect representative random sample, especially when selected observations are impacted by the outcome of the interest, which then triggers a bias of the estimated coefficients in the regressions (Heckman et al., 1998). In our case, those MFIs which are already using digital tools or planning to introduce digitization show more interest in responding to our survey. Moreover, respondents may intend to self-select their preferred options due to the voluntary disclosure to the survey. Thus, inconsistent estimations could arise. To address this issue, one of the most common approaches used in research is the Heckman selection model (Tucker, 2010; Wu and Shen, 2013; Lee et al., 2015). We run a Heckman two-part model with a separate probit estimation for sample inclusion and maximum likelihood. The estimation of a probit model for selection is initially included to investigate the probability of MFIs responding to the survey. In this first step, Answer is our dependent dummy variable, indicating whether or not MFIs have responded to the Yapu solutions survey. Determinants employed in this paper include an MFI's age, the logarithm of total assets, the average loan balance to borrower divided by GNI per capita, legal status as well as the domestic credit and dispute resolution index of the reference country (see Table 1 for more details). After controlling for the correction of selection bias, we are then able to proceed with the estimation of determinants of the adoption of digital solutions by MFIs. Under the condition that Answer takes the value of 1 , we assess the likelihood of the integration of digital solutions based on the set of explanatory variables described in Table 1. A p-value smaller than 0.05 of the Wald test of independent equations indicates that the model is appropriate and there is the presence of selection bias.

\subsection{Descriptive statistics}

Table 2 and Table 3 display the sample characteristics by the response status and the use of digital solutions correspondingly. At first glance, one can see that our sample reflects the diverse microfinance sector. In the data sample, a predominance of MFIs from Latin America and the Caribbean can be found, 
accounting for a total of $34.55 \%$. Moreover, MFIs of type NGO tend to be active in answering the questionnaire with the proportion of the response rate being higher than that of the rejection rate $(47.62 \%$ compared with $27.87 \%$ ). As expected, the higher the trustworthiness ranking of an MFI, the more likely they are to participate in the survey. To be more specific, the proportion of unrated MFIs in the responded group is less than half that of those who are in the abstained group ( $7.62 \%$ in comparison to $18.32 \%$ ). Meanwhile, the statistics are more positive in the case of MFIs who have high rating scores. The percentage of this type of MFIs is approximately $10 \%$ greater in the responded group than the non-responded one $(56.19 \%$ compared with $46.76 \%$ ).

Regarding the characteristics of MFIs who are using and not using digital solutions, institutions located in LAC and South Asia tend to favor the integration of digital solutions more than other regions. In terms of legal status, MFIs of the type NGO exhibit more interest in digital solutions than the other types with $51.09 \%$ of observations using these tools being NGOs. Among the MFIs adopting digital solutions, institutions ranked high by MIX Market show an over-representation, accounting for $57.61 \%$ of the observations.

Table 4 compares the descriptive statistics between respondents and nonrespondents. The results reveal that MFIs who responded to the survey appear to be more mature in terms of age than their counterparts. No significant difference regarding total assets can be ascertained between the two groups of MFIs. The same holds true for the dispute resolution index. Regarding the domestic credit variable, the statistics indicate that MFIs located in countries with more developed financial markets appear to be more interested in the survey than their counterparts. However, the difference in the mean value is not notable.

Table 5 illustrates descriptive statistics for the explanatory variables related to our estimations for MFIs with and without digital solutions. In line with our assumption, MFIs that use digital solutions have a higher percentage of female borrowers and lower average real yield on gross loan portfolios $(0.7 \%$ compared to $0.54 \%$ and $0.25 \%$ compared to $0.29 \%$, respectively). Furthermore, institutions with the use of digital tools exhibit, on average, a higher return on equity compared with those without digital solutions. These results allow us to make initial predictions for the significant impacts of the 
Table 2: Frequency table by response status

\begin{tabular}{|c|c|c|c|c|c|c|}
\hline & \multicolumn{2}{|c|}{ No } & \multicolumn{2}{|c|}{ Yes } & \multicolumn{2}{|c|}{ Total } \\
\hline & Obs & $\%$ & Obs & $\%$ & Obs & $\%$ \\
\hline \multicolumn{7}{|l|}{ Region } \\
\hline Africa and MENA & 202 & 22.98 & 23 & 21.90 & 225 & 22.87 \\
\hline EAP & 114 & 12.97 & 15 & 14.29 & 129 & 13.11 \\
\hline EECA & 118 & 13.42 & 13 & 12.38 & 131 & 13.31 \\
\hline $\mathrm{LAC}$ & 306 & 34.81 & 34 & 32.38 & 340 & 34.55 \\
\hline South Asia & 139 & 15.81 & 20 & 19.05 & 159 & 16.16 \\
\hline \multicolumn{7}{|l|}{ Type } \\
\hline Bank and others & 180 & 20.48 & 10 & 9.52 & 190 & 19.31 \\
\hline Credit & 121 & 13.77 & 10 & 9.52 & 131 & 13.31 \\
\hline \multicolumn{7}{|l|}{ Union/Cooperative } \\
\hline NBFI & 333 & 37.88 & 35 & 33.33 & 368 & 37.40 \\
\hline NGO & 245 & 27.87 & 50 & 47.62 & 295 & 29.98 \\
\hline \multicolumn{7}{|l|}{ Diamonds } \\
\hline Unrated & 161 & 18.32 & 8 & 7.62 & 169 & 17.17 \\
\hline Low & 307 & 34.93 & 38 & 36.19 & 345 & 35.06 \\
\hline High & 411 & 46.76 & 59 & 56.19 & 470 & 47.76 \\
\hline $\mathbf{N}$ & 879 & & 105 & & 984 & \\
\hline
\end{tabular}

\section{Empirical results}

\section{Determinants of the digital solution adoption of MFIs}

This section discusses the results obtained from estimating the above equation using a probit model with robust standard errors. In Table 7, while 
Table 3: Frequency table by the use of digital solutions

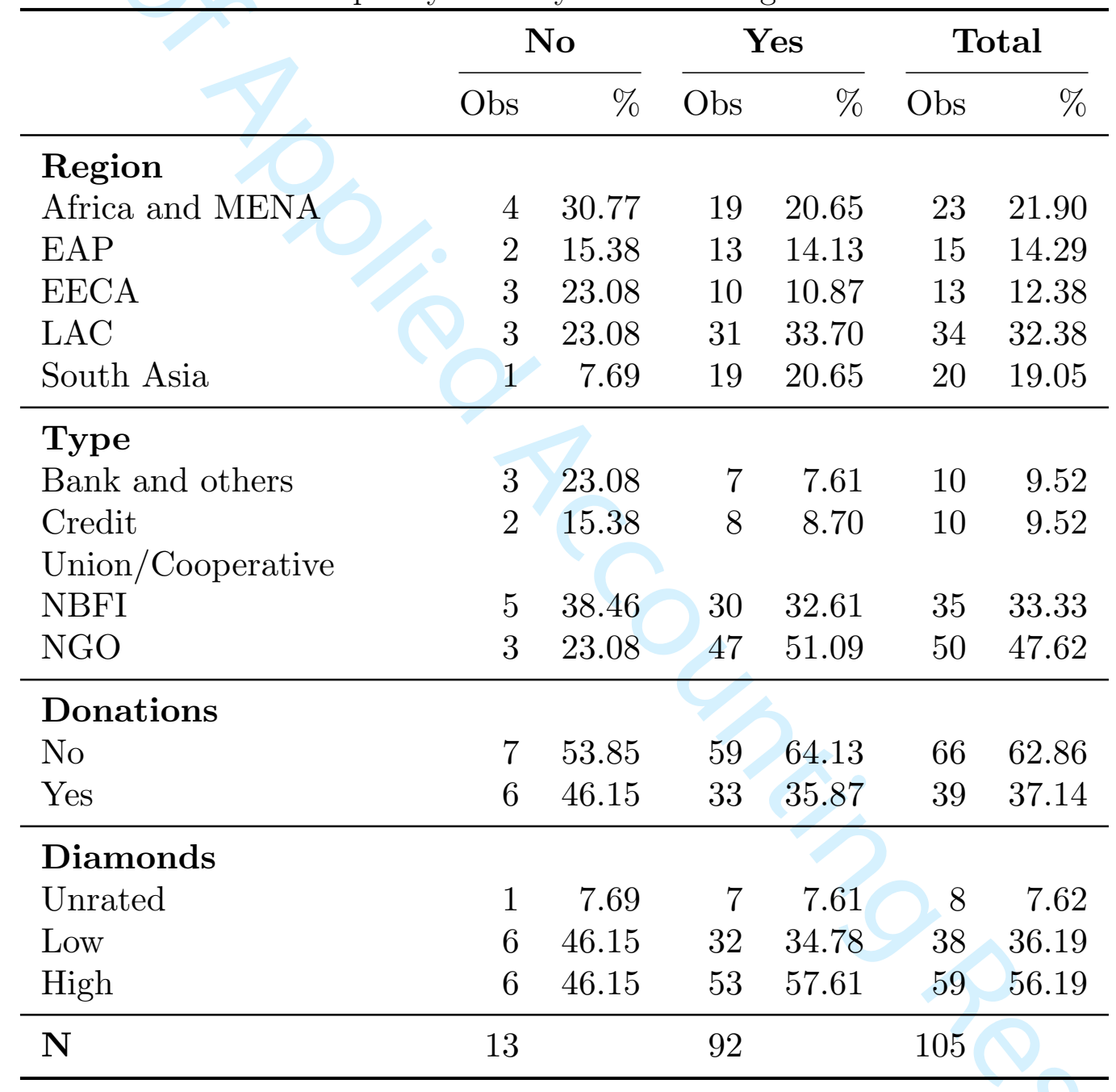


Table 4: Descriptive statistics of metric variables by response status

\begin{tabular}{|c|c|c|c|c|c|c|}
\hline & \multicolumn{2}{|c|}{ No } & \multicolumn{2}{|c|}{ Yes } & \multicolumn{2}{|c|}{ Total } \\
\hline & Mean & $\mathrm{SD}$ & Mean & $\mathrm{SD}$ & Mean & $\mathrm{SD}$ \\
\hline Age & 19.41 & 10.35 & 20.57 & 9.28 & 19.53 & 10.25 \\
\hline Assets (ln) & 16.41 & 2.15 & 16.50 & 1.89 & 16.42 & 2.12 \\
\hline DTE & 3.51 & 8.68 & 4.34 & 4.14 & 3.60 & 8.32 \\
\hline GLP (ln) & 16.07 & 2.24 & 16.21 & 2.00 & 16.08 & 2.21 \\
\hline Female & 0.65 & 0.23 & 0.68 & 0.23 & 0.65 & 0.23 \\
\hline ALBGNI & 0.59 & 1.18 & 0.44 & 0.53 & 0.58 & 1.12 \\
\hline Yield (r) & 0.27 & 0.17 & 0.26 & 0.14 & 0.26 & 0.17 \\
\hline $\mathrm{ROE}$ & 0.06 & 0.31 & 0.07 & 0.27 & 0.06 & 0.30 \\
\hline OEA & 0.18 & 0.13 & 0.18 & 0.11 & 0.18 & 0.13 \\
\hline PAR30 & 0.07 & 0.10 & 0.07 & 0.13 & 0.07 & 0.11 \\
\hline GDPpc (ln) & 7.84 & 0.95 & 7.67 & 0.89 & 7.83 & 0.94 \\
\hline DOMCRE & 50.86 & 27.70 & 51.12 & 26.54 & 50.89 & 27.57 \\
\hline WOR & 0.02 & 0.04 & 0.02 & 0.02 & 0.02 & 0.04 \\
\hline Rural & 0.52 & 0.27 & 0.58 & 0.26 & 0.52 & 0.27 \\
\hline Dispute & 0.77 & 0.34 & 0.72 & 0.35 & 0.76 & 0.35 \\
\hline Observations & 879 & & 105 & & 984 & \\
\hline
\end{tabular}


Table 5: Descriptive statistics of metric variables by the the use of digital solutions

\begin{tabular}{|c|c|c|c|c|c|c|}
\hline & \multicolumn{2}{|c|}{ No } & \multicolumn{2}{|c|}{ Yes } & \multicolumn{2}{|c|}{ Total } \\
\hline & Mean & SD & Mean & $\mathrm{SD}$ & Mean & $\mathrm{SD}$ \\
\hline Age & 16.92 & 7.42 & 21.09 & 9.44 & 20.57 & 9.28 \\
\hline Assets (ln) & 15.79 & 1.96 & 16.60 & 1.87 & 16.50 & 1.89 \\
\hline DTE & 6.01 & 5.47 & 4.10 & 3.90 & 4.34 & 4.14 \\
\hline GLP $(\ln )$ & 15.51 & 1.94 & 16.31 & 2.00 & 16.21 & 2.00 \\
\hline Female & 0.54 & 0.18 & 0.70 & 0.23 & 0.68 & 0.23 \\
\hline ALBGNI & 0.73 & 0.63 & 0.40 & 0.50 & 0.44 & 0.53 \\
\hline Yield (r) & 0.29 & 0.14 & 0.25 & 0.14 & 0.26 & 0.14 \\
\hline $\mathrm{ROE}$ & -0.08 & 0.42 & 0.09 & 0.24 & 0.07 & 0.27 \\
\hline OEA & 0.21 & 0.15 & 0.18 & 0.10 & 0.18 & 0.11 \\
\hline PAR30 & 0.12 & 0.15 & 0.06 & 0.12 & 0.07 & 0.13 \\
\hline GDPpc (ln) & 7.19 & 0.75 & 7.74 & 0.89 & 7.67 & 0.89 \\
\hline DOMCRE & 30.18 & 19.35 & 54.08 & 26.16 & 51.12 & 26.54 \\
\hline Dispute & 0.49 & 0.36 & 0.75 & 0.34 & 0.72 & 0.35 \\
\hline WOR & 0.02 & 0.03 & 0.02 & 0.02 & 0.02 & 0.02 \\
\hline Rural & 0.59 & 0.16 & 0.58 & 0.28 & 0.58 & 0.26 \\
\hline Observations & 13 & & 92 & & 105 & \\
\hline
\end{tabular}

Table 6: Correlation - imputed data

\begin{tabular}{|c|c|c|c|c|c|c|c|c|c|c|c|c|c|c|}
\hline & 1 & 2 & 3 & 4 & 5 & 6 & 7 & 8 & 9 & 10 & 11 & 12 & 13 & 14 \\
\hline 1.Age & 1.00 & & & & & & & & & & & & & \\
\hline 2.Assets (ln) & $0.30^{* * *}$ & $* 1.00$ & & & & & & & & & & & & \\
\hline 3.DTE & $0.11^{* * *}$ & ${ }^{*} 0.16^{* * *}$ & * 1.00 & & & & & & & & & & & \\
\hline 4.Female & -0.01 & $-0.09^{* * *}$ & * 0.00 & 1.00 & & & & & & & & & & \\
\hline 5.ALBGNI & -0.04 & $0.15^{* * *}$ & $* 0.05$ & $-0.28^{* * *}$ & $* 1.00$ & & & & & & & & & \\
\hline 6.Yield (r) & $-0.21^{* * *}$ & ${ }^{*}-0.19^{* * *}$ & ${ }^{*}-0.06^{*}$ & $0.12^{* * *}$ & ${ }^{*}-0.15^{* * *}$ & $*^{*} 1.00$ & & & & & & & & \\
\hline 7.ROE & $0.07^{* *}$ & $0.13^{* * *}$ & ${ }^{*}-0.02$ & $0.11^{* * *}$ & * 0.01 & -0.01 & 1.00 & & & & & & & \\
\hline 8.OEA & $-0.25^{* * *}$ & ${ }^{*}-0.31^{* * *}$ & ${ }^{*}-0.12^{* * *}$ & ${ }^{* *} 0.14^{* * *}$ & ${ }^{*}-0.16^{* * *}$ & $* 0.77^{* * *}$ & $-0.22^{* * *}$ & $* 1.00$ & & & & & & \\
\hline 9.GDPpc (ln) & $0.17^{* * *}$ & * $0.09^{* * *}$ & * 0.04 & $-0.07^{* *}$ & $-0.25^{* * *}$ & $* 0.25^{* * *}$ & 0.02 & $0.16^{* * *}$ & 1.00 & & & & & \\
\hline 10.DOMCRE & 0.05 & 0.01 & 0.03 & $0.27^{* * *}$ & ${ }^{*}-0.13^{* * *}$ & ${ }^{*}-0.23^{* * *}$ & $0.10^{* * *}$ & $* 0.17^{* * *}$ & $0.18^{* *}$ & $* 1.00$ & & & & \\
\hline 11.Dispute & $0.17^{* * *}$ & * $0.10^{* * *}$ & * $0.07^{* *}$ & $0.05^{*}$ & $-0.19^{* * *}$ & $* 0.09^{* * *}$ & 0.01 & $0.08^{* *}$ & $0.34^{* *}$ & $*-0.06^{* *}$ & 1.00 & & & \\
\hline 12.PAR30 & 0.01 & $-0.08^{* *}$ & $-0.06^{* *}$ & $-0.26^{* *}$ & 0.01 & $-0.02-$ & $-0.12^{* * *}$ & $* 0.09^{* * *}$ & 0.02 & $-0.13^{* * *}$ & 0.00 & 1.00 & & \\
\hline 13.WOR & $-0.07^{* *}$ & -0.01 & -0.02 & -0.03 & -0.04 & $0.32^{* * *}$ & $-0.13^{* * *}$ & * $0.29^{* * *}$ & $0.13^{* *}$ & $*-0.07^{* *}$ & $0.06^{*}$ & $0.11^{* *}$ & $* 1.00$ & \\
\hline 14.Rural & -0.01 & -0.05 & 0.02 & $0.17^{* * *}$ & ${ }^{*}-0.11^{* * *}$ & $* 0.16^{* * *}$ & $0.06^{*}$ & $-0.14^{* * *}$ & $-0.16^{* *}$ & $* 0.14^{* * *}$ & $-0.14^{* *-}$ & ${ }^{*}-0.07^{* *}$ & $-0.09^{* * *}$ & $*^{*} 1.00$ \\
\hline
\end{tabular}


model specifications (1), (2), and (3) focus on different characteristics of MFIs separately, the model specification (4) displays the full model with all the explanatory variables. The model specification (5) presents the regression results for the Heckman model. All regressions are investigated with the inclusion of the entire control variables mentioned above.

The coefficients of the debt to equity ratio show a significantly negative sign in the model specification (1) and (4), indicating that MFIs that depend less on external sources of funding tend to utilize digital solutions. The models also reveal that with the increasing size of the MFIs, which is measured by total assets, the probability of employing digital solutions also increases as the coefficients reveal themselves to be significant and positive at the $5 \%$ level in the two models. This finding is consistent with the previous literature on the impact of economies of scale on the introduction of financial technology support solutions (Pytkowska and Korynski, 2017). A lack of funding resources is one of the barriers that prevents the application of software solutions. For the coefficient of the age of MFIs, a positive but insignificant sign can be observed in both models, which implies that there is no clear effect on the adoption of digital solutions.

The regression results in columns (2) and (4) show that our hypothesis related to the correlation between the social performance of MFIs and the adoption of digital solutions (H1) is supported. First, the significance and positive sign of the coefficients suggest that MFIs that focus on lending to women tend to integrate digital solutions into their business. One possible interpretation for the significant relationship between the percentage of female borrowers and the likelihood of adopting digital solutions may be attributed to the explicit social orientation of the microfinance sector. Although microfinance is considered as an effective tool in poverty alleviation Quinones and Remenyi, 2014), the impact on women empowerment or higher income still remains unclear (Brau and Woller, 2004, Banerjee et al., 2015). Therefore, a new approach to the microfinance business model which can create more benefits for female customers is necessary. Under these circumstances, digital technology can serve as an effective solution that will bring women empowerment. Although the effects of the average loan balance prove to be insignificant, the negative sign of coefficients provides no evidence of the mission drift of MFIs related to the application of digital solutions. Therefore, it is quite clear that those MFIs which strive for better outreach are more likely to engage in the application of IT solutions. 
Furthermore, we detect significant evidence of the impact of the yield on gross loan portfolios on an MFI's digital solution adoption. The coefficients remain negative and are significant in both specifications, suggesting that the utilization of digital solutions does not necessarily need to be related to a heavier burden on customers through increasing financial revenues, i.e, a higher interest rate. Despite the high upfront costs of implementing digital solutions, we suppose that MFIs are able to handle this problem with the outside source of finance rather than raising interest rates which would, in turn, harm their social goals. According to (Hudon and Traca, 2011), subsidies prove to be an effective outside source of finance that positively influence the efficiency of MFIs. Furthermore, it is empirically evidenced that high interest rates are associated with unsubsidized MFIs in African and Asian (D'Espallier et al., 2013). Hence, we argue that the relationship between a low portfolio yield and the adoption of digital software may be linked to the existence of subsidies. Furthermore, as previously mentioned in the above discussion on the relationship between stakeholder theory and CSR strategy, MFIs that prioritize the demand of their low-income customers can benefit from digital initiatives in the sense of a better delivery of financial services to their customers, especially to those living in remote and rural areas. Altogether, we can support the argument that there is a positive relationship between the MFI's social performance and the utilization of digital solutions.

Regarding H2, we only find weak evidence in favor of this hypothesis. The indicated results in regressions (2) and (4) reveal the significant effects of returns at the $10 \%$ level. The positive relationship between the variable $(R O E)$ and the MFI's intention of adopting digital solutions implies that MFIs with digital solutions can exhibit higher returns. These outcomes are consistent with our hypothesis H2, which leads us to the conclusion that more profitable MFIs are more likely to adopt digital tools. Next, we discuss the findings concerning the effect of economic development (H3). We find supporting evidence for H3. As illustrated in the model specification (3) and (4), the coefficients of the variable GDPpc (ln) possess the expected positive sign, which validates the assumption that economic development influences the adoption of digital solutions. This provides a sound reason in favor of the argument that a higher level of development provides positive role models to the integration of digital solutions. 


\section{Heckman two-stage estimations}

As discussed above, our regressions may suffer from the problem of selection bias, which can trigger inconsistent results. This is due to the nature of the survey since MFIs are not obligated to respond to the survey. Those MFIs that are unobservable in our analysis have a negative effect on the error term. Therefore, a Heckman selection model with Answer as the binary dependent variable in the selection stage is further employed to overcome this problem. In addition to the explanatory variables included in the main model, namely Age, Assets, ALBGNI, and type of MFIs, we further include two macroeconomic variables, which control for the country-level effects, i.e., DOMCRE and Dispute (see Table 1).

As shown in column (5), the results confirm our hypotheses-related findings with the level of significance largely remaining unchanged. We observe a slight change to $10 \%$ in the significance of the coefficient for the variable of the percentage of female borrowers. However, the sign of the correlation remains positive. Furthermore, we find our prediction on the difference in the response rate among types of MFIs to be true. To be more specific, we depict a strong and positive association between MFIs of the type NGO and the likelihood of participating in the survey. Moreover, there is no relationship between the percentage of domestic credit to GDP and the possibility of a response.

\section{Robustness checks}

To test for the strength and validity of our results, we further conduct several robustness tests by modifying the specification of the regressions (see Table 8) and by employing different measures for digital solutions (see Table 13). First, the results illustrated in Table 8 show slight differences. To be more specific, we examine the robustness of the models in the absence of the variable Female (model specification (2) and (5)). In comparison with our baseline models (model specification (1) and (4)), it is interesting to observe the negative and significant relationship between $A L B G N I$ and the introduction of digital solutions, which means the lower the average loan balance the higher the probability of introducing digital solutions. Since both of these variables are good proxies for an MFI's social performance, this observation 
Table 7: Estimation results

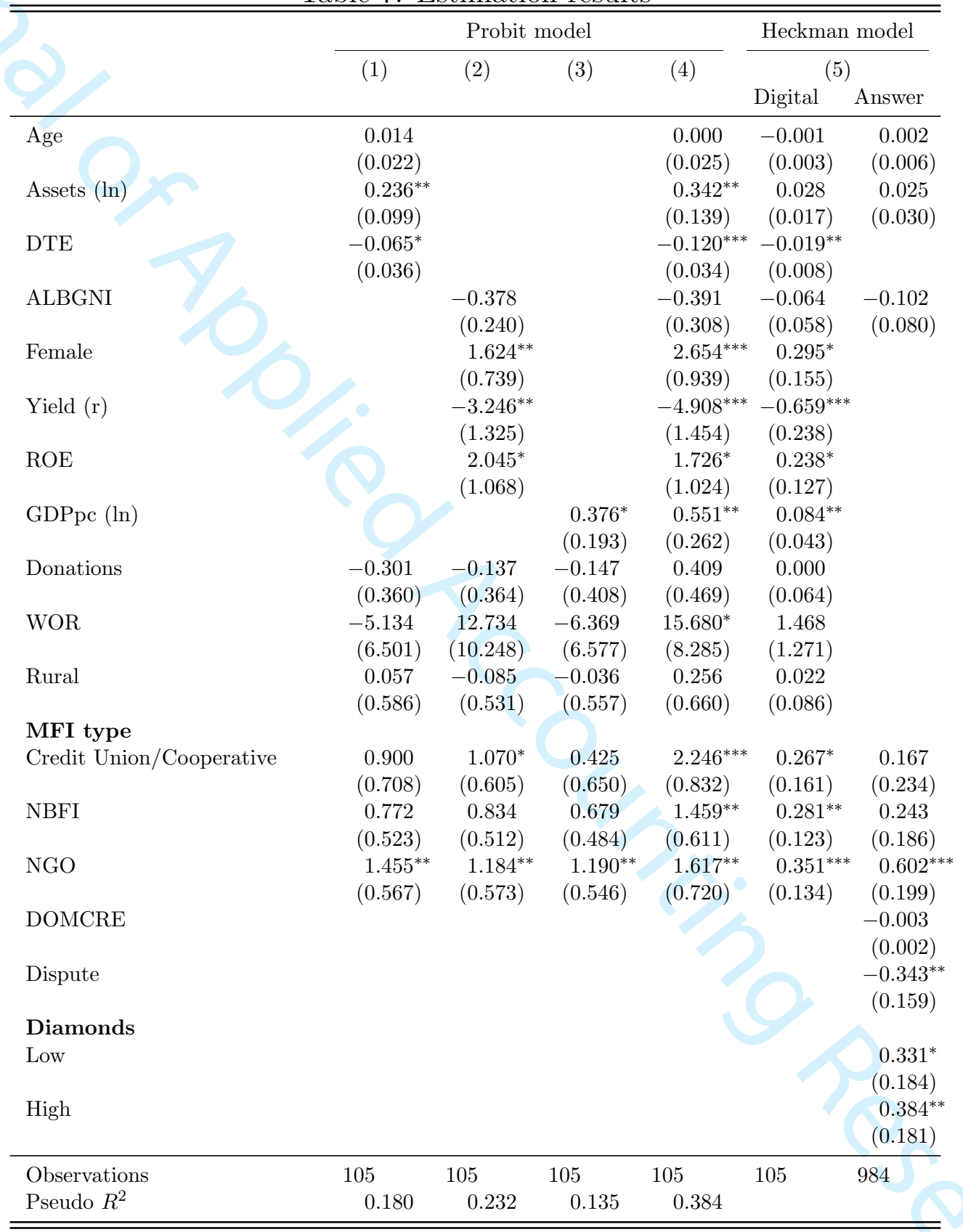

Model specifications (1)-(4) are probit model with Digital as dependent variable. Model (5) presents the results of Heckman estimations with Answer and Digital being dependent variables in the first and second stage of the Heckman model, respectively. Variables are defined in Table 1 .

Standard errors in parentheses: ${ }^{*} p<0.1,{ }^{* *} p<0.05,{ }^{* * *} p<0.01$ 
again supports hypothesis H1. Furthermore, the robustness tests display a significant and negative relation between portfolio yields and an MFI's adoption of digital supporting solutions, confirming the argument that MFIs can utilize digital solutions while keeping low interest rates. These findings confirm our evidence concerning the relationship between an MFI's social performance and the adoption of digital tools (H1). To investigate whether institutions using digital solutions have lower operating expenses, we additionally run estimations for which $O E A$ is added as an explanatory variable (model specification (3) and (6)). The coefficients of interest show negative signs that are significant at the $5 \%$ level, suggesting that MFIs that are good at controlling their expenses tend to engage more frequently in digital solutions.

Second, we use two alternative digital solutions proxies, namely the variables Apps and Software (see Table 1 for detailed definitions). Descriptive statistics through the use of Apps and Smartphones are provided in Table 9 through Table 12. The regression results are shown in Table 13 . Indeed, we find no significant changes in the relationship between the variable Female and our dependent variables. In other words, MFIs with better social performance are more likely to be involved in the use of digital tools, confirming the robustness of our results when using different measures for digital solutions. Furthermore, the results illustrate the absence of significant coefficients among the variables ROE, Yield and GDPpc (ln) and the two dependent variables of interest. One possible explanation for this is that in the case of more advanced digitized products such as apps/software for tablets or smartphones in the fields, performance risks or the resources for the adoption becomes less important (Kim et al. 2017).

\section{Conclusion}

Although the remarkable innovation in digitizing microfinance as a whole and its important role in financial inclusion are increasingly gaining the attention of scholars and policymakers, this area of research appears to remain under-documented. The purpose of the article is to unveil the global trends regarding the adoption of digital solutions in the microfinance sector and to understand the factors that are related to the digitization of MFIs. With the 
Table 8: Robustness tests for Digital solutions

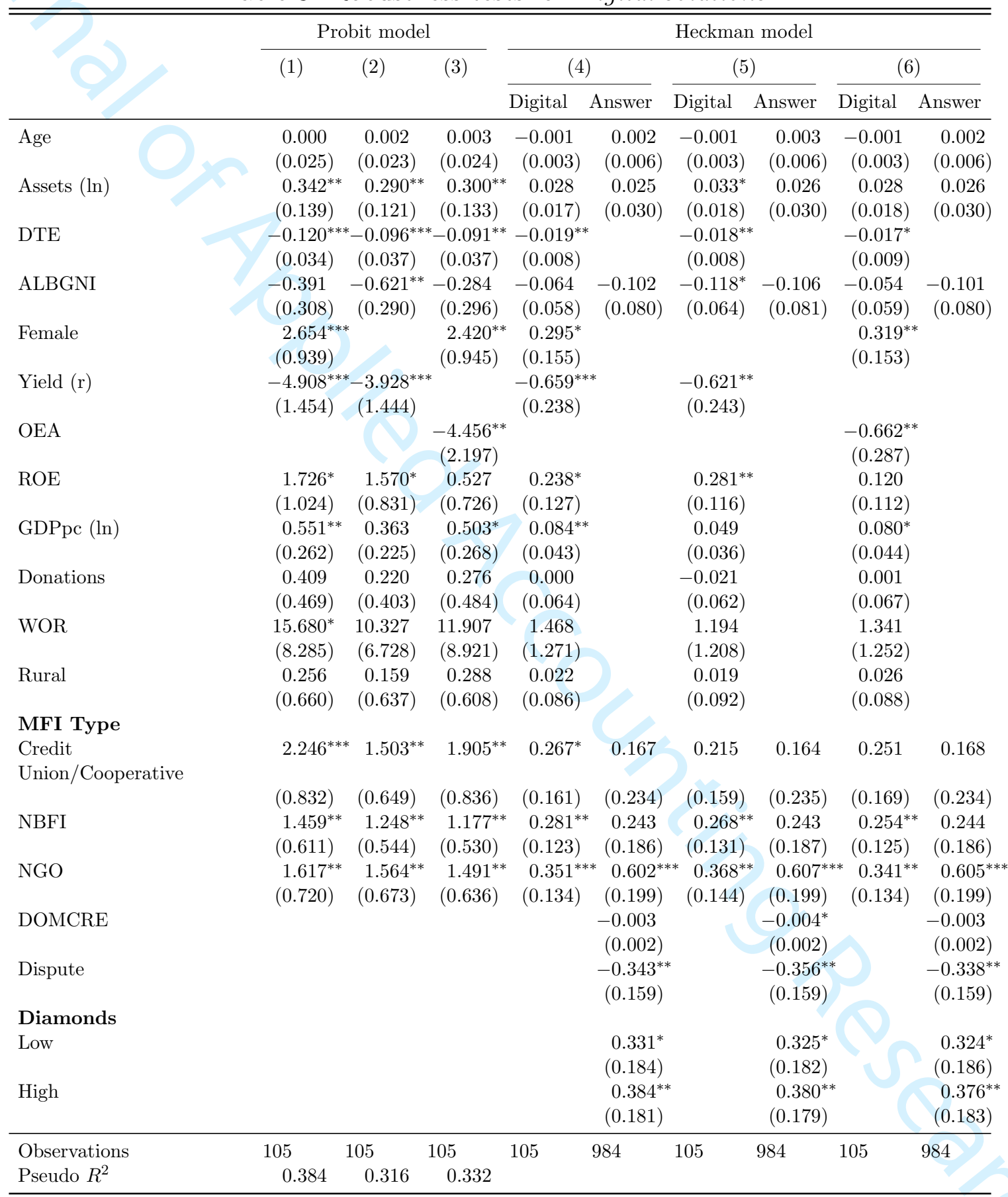

Variables are defined in Table 1.

Standard errors in parentheses: ${ }^{*} p<0.1,{ }^{* *} p<0.05,{ }^{* * *} p<0.01$ 
Table 9: Frequency table by the use of Apps

\begin{tabular}{lrrrrrr}
\hline & \multicolumn{2}{c}{ No } & \multicolumn{3}{c}{ Yes } & \multicolumn{3}{c}{ Total } \\
& Obs & $\%$ & Obs & $\%$ & Obs & $\%$ \\
\hline Region & & & & & & \\
Africa and MENA & 16 & 27.59 & 7 & 14.89 & 23 & 21.90 \\
EAP & 7 & 12.07 & 8 & 17.02 & 15 & 14.29 \\
EECA & 9 & 15.52 & 4 & 8.51 & 13 & 12.38 \\
LAC & 18 & 31.03 & 16 & 34.04 & 34 & 32.38 \\
South Asia & 8 & 13.79 & 12 & 25.53 & 20 & 19.05 \\
\hline Type & & & & & & \\
Bank and others & 6 & 10.34 & 4 & 8.51 & 10 & 9.52 \\
Credit Union/Cooperative & 7 & 12.07 & 3 & 6.38 & 10 & 9.52 \\
NBFI & 19 & 32.76 & 16 & 34.04 & 35 & 33.33 \\
NGO & 26 & 44.83 & 24 & 51.06 & 50 & 47.62 \\
\hline Diamonds & & & & & & \\
Unrated & 7 & 12.07 & 1 & 2.13 & 8 & 7.62 \\
Low & 23 & 39.66 & 15 & 31.91 & 38 & 36.19 \\
High & 28 & 48.28 & 31 & 65.96 & 59 & 56.19 \\
\hline $\mathbf{N}$ & 58 & & 47 & & 105 & \\
\hline
\end{tabular}

Table 10: Frequency table by the use of Software

\begin{tabular}{lrrrrrrr}
\hline & \multicolumn{2}{c}{ No } & \multicolumn{3}{c}{ Yes } & \multicolumn{3}{c}{ Total } \\
& Obs & $\%$ & Obs & $\%$ & Obs & $\%$ \\
\hline Region & & & & & & \\
Africa and MENA & 17 & 23.94 & 6 & 17.65 & 23 & 21.90 \\
EAP & 11 & 15.49 & 4 & 11.76 & 15 & 14.29 \\
EECA & 10 & 14.08 & 3 & 8.82 & 13 & 12.38 \\
LAC & 23 & 32.39 & 11 & 32.35 & 34 & 32.38 \\
South Asia & 10 & 14.08 & 10 & 29.41 & 20 & 19.05 \\
\hline Type & & & & & & \\
Bank and others & 7 & 9.86 & 3 & 8.82 & 10 & 9.52 \\
Credit Union/Cooperative & 8 & 11.27 & 2 & 5.88 & 10 & 9.52 \\
NBFI & 24 & 33.80 & 11 & 32.35 & 35 & 33.33 \\
NGO & 32 & 45.07 & 18 & 52.94 & 50 & 47.62 \\
\hline Diamonds & & & & & & \\
Unrated & 7 & 9.86 & 1 & 2.94 & 8 & 7.62 \\
Low & 27 & 38.03 & 11 & 32.35 & 38 & 36.19 \\
High & 37 & 52.11 & 22 & 64.71 & 59 & 56.19 \\
\hline $\mathbf{N}$ & 71 & & 34 & & 105 & \\
\hline
\end{tabular}


Table 11: Descriptive statistics of metric variables by the use of Apps

\begin{tabular}{|c|c|c|c|c|c|c|}
\hline & \multicolumn{2}{|c|}{ No } & \multicolumn{2}{|c|}{ Yes } & \multicolumn{2}{|c|}{ Total } \\
\hline & Mean & $\mathrm{SD}$ & Mean & SD & Mean & SD \\
\hline Age & 18.55 & 8.50 & 23.06 & 9.69 & 20.57 & 9.28 \\
\hline Assets (ln) & 15.76 & 1.57 & 17.42 & 1.86 & 16.50 & 1.89 \\
\hline DTE & 4.18 & 4.32 & 4.53 & 3.94 & 4.34 & 4.14 \\
\hline Female & 0.61 & 0.23 & 0.76 & 0.20 & 0.68 & 0.23 \\
\hline ALBGNI & 0.53 & 0.62 & 0.32 & 0.36 & 0.44 & 0.53 \\
\hline Yield (r) & 0.25 & 0.13 & 0.27 & 0.16 & 0.26 & 0.14 \\
\hline OEA & 0.18 & 0.11 & 0.18 & 0.11 & 0.18 & 0.11 \\
\hline $\mathrm{ROE}$ & 0.03 & 0.24 & 0.12 & 0.30 & 0.07 & 0.27 \\
\hline GDPpc (ln) & 7.55 & 0.95 & 7.82 & 0.79 & 7.67 & 0.89 \\
\hline DOMCRE & 46.96 & 26.75 & 56.26 & 25.65 & 51.12 & 26.54 \\
\hline Dispute & 0.69 & 0.35 & 0.75 & 0.36 & 0.72 & 0.35 \\
\hline WOR & 0.02 & 0.03 & 0.02 & 0.02 & 0.02 & 0.02 \\
\hline Rural & 0.58 & 0.26 & 0.58 & 0.27 & 0.58 & 0.26 \\
\hline Observations & 58 & & 47 & & 105 & \\
\hline
\end{tabular}

Table 12: Descriptive statistics of metric variables by the use of Software

\begin{tabular}{|c|c|c|c|c|c|c|}
\hline & \multicolumn{2}{|c|}{ No } & \multicolumn{2}{|c|}{ Yes } & \multicolumn{2}{|c|}{ Total } \\
\hline & Mean & $\mathrm{SD}$ & Mean & $\mathrm{SD}$ & Mean & $\mathrm{SD}$ \\
\hline Age & 19.46 & 9.07 & 22.88 & 9.44 & 20.57 & 9.28 \\
\hline Assets (ln) & 16.10 & 1.73 & 17.34 & 1.96 & 16.50 & 1.89 \\
\hline DTE & 4.48 & 4.71 & 4.03 & 2.59 & 4.34 & 4.14 \\
\hline Female & 0.63 & 0.23 & 0.77 & 0.20 & 0.68 & 0.23 \\
\hline ALBGNI & 0.48 & 0.57 & 0.34 & 0.40 & 0.44 & 0.53 \\
\hline Yield (r) & 0.25 & 0.14 & 0.26 & 0.16 & 0.26 & 0.14 \\
\hline OEA & 0.18 & 0.11 & 0.18 & 0.11 & 0.18 & 0.11 \\
\hline $\mathrm{ROE}$ & 0.06 & 0.30 & 0.09 & 0.20 & 0.07 & 0.27 \\
\hline GDPpc (ln) & 7.63 & 0.92 & 7.76 & 0.84 & 7.67 & 0.89 \\
\hline DOMCRE & 48.91 & 27.33 & 55.74 & 24.57 & 51.12 & 26.54 \\
\hline Dispute & 0.70 & 0.36 & 0.76 & 0.33 & 0.72 & 0.35 \\
\hline WOR & 0.02 & 0.03 & 0.02 & 0.02 & 0.02 & 0.02 \\
\hline Rural & 0.59 & 0.25 & 0.57 & 0.29 & 0.58 & 0.26 \\
\hline Observations & 71 & & 34 & & 105 & \\
\hline
\end{tabular}


Table 13: Robustness checks: Analyzing with different measures of Digital Solutions

\begin{tabular}{|c|c|c|c|c|c|c|c|c|}
\hline \multirow[b]{3}{*}{ Dependent variable } & \multicolumn{4}{|c|}{ Probit model } & \multicolumn{4}{|c|}{ Heckman model } \\
\hline & (1) & $(2)$ & (3) & (4) & \multicolumn{2}{|c|}{$(5)$} & \multicolumn{2}{|l|}{$(6)$} \\
\hline & \multicolumn{2}{|c|}{ Apps } & \multicolumn{2}{|c|}{ Software } & Apps & Answer $\mathrm{s}$ & Software & Answer \\
\hline Age & $\begin{array}{c}0.014 \\
(0.020)\end{array}$ & $\begin{array}{c}0.016 \\
(0.018)\end{array}$ & $\begin{array}{c}0.003 \\
(0.019)\end{array}$ & $\begin{array}{c}0.003 \\
(0.018)\end{array}$ & $\begin{array}{c}0.004 \\
(0.006)\end{array}$ & $\begin{array}{c}0.002 \\
(0.006)\end{array}$ & $\begin{array}{c}0.000 \\
(0.006)\end{array}$ & $\begin{array}{c}0.002 \\
(0.006)\end{array}$ \\
\hline Assets (ln) & $\begin{array}{l}0.526^{* * *} \\
(0.110)\end{array}$ & * $\begin{array}{l}0.481^{* * * *} \\
(0.099)\end{array}$ & $\begin{array}{rl}* & 0.296 * * * * \\
& (0.085)\end{array}$ & $\begin{aligned} & 0.299^{* * *} \\
& (0.083)\end{aligned}$ & $\begin{array}{l}0.117^{* * *} \\
(0.022)\end{array}$ & * $\begin{array}{c}0.024 \\
(0.030)\end{array}$ & $\begin{array}{l}0.086^{* * *} \\
(0.023)\end{array}$ & $\begin{array}{c}0.025 \\
(0.030)\end{array}$ \\
\hline DTE & $\begin{array}{c}-0.002 \\
(0.038)\end{array}$ & $\begin{array}{c}0.026 \\
(0.036)\end{array}$ & $\begin{array}{c}-0.037 \\
(0.034)\end{array}$ & $\begin{array}{c}-0.021 \\
(0.032)\end{array}$ & $\begin{array}{c}0.002 \\
(0.011)\end{array}$ & & $\begin{array}{c}-0.009 \\
(0.009)\end{array}$ & \\
\hline ALBGNI & $\begin{array}{c}-0.454 \\
(0.315)\end{array}$ & $\begin{array}{c}-0.954^{* *} \\
(0.403)\end{array}$ & $\begin{array}{c}-0.147 \\
(0.311)\end{array}$ & $\begin{array}{c}-0.505 \\
(0.340)\end{array}$ & $\begin{array}{c}-0.112 \\
(0.086)\end{array}$ & $\begin{array}{c}-0.092 \\
(0.078)\end{array}$ & $\begin{array}{c}-0.047 \\
(0.091)\end{array}$ & $\begin{array}{c}-0.091 \\
(0.077)\end{array}$ \\
\hline Female & $\begin{array}{c}2.588^{* * *} \\
(0.779)\end{array}$ & & $\begin{array}{l}1.954^{* *} \\
(0.791)\end{array}$ & & $\begin{array}{l}0.705^{* * *} \\
(0.197)\end{array}$ & & $\begin{array}{l}0.577^{* * *} \\
(0.217)\end{array}$ & \\
\hline Yield (r) & $\begin{array}{c}1.850 \\
(1.291)\end{array}$ & $\begin{array}{c}1.609 \\
(1.219)\end{array}$ & $\begin{array}{c}0.552 \\
(1.036)\end{array}$ & $\begin{array}{c}0.571 \\
(1.050)\end{array}$ & $\begin{array}{l}0.337 \\
(0.274)\end{array}$ & & $\begin{array}{c}0.172 \\
(0.319)\end{array}$ & \\
\hline ROE & $\begin{array}{c}-0.209 \\
(0.561)\end{array}$ & $\begin{array}{l}0.196 \\
(0.547)\end{array}$ & $\begin{array}{c}-0.482 \\
(0.518)\end{array}$ & $\begin{array}{c}-0.244 \\
(0.507)\end{array}$ & $\begin{array}{c}-0.027 \\
(0.155)\end{array}$ & & $\begin{array}{c}-0.148 \\
(0.165)\end{array}$ & \\
\hline GDPpc (ln) & $\begin{array}{c}0.105 \\
(0.215)\end{array}$ & $\begin{array}{c}-0.151 \\
(0.183)\end{array}$ & $\begin{array}{c}0.026 \\
(0.205)\end{array}$ & $\begin{array}{c}-0.175 \\
(0.180)\end{array}$ & $\begin{array}{c}0.058 \\
(0.055)\end{array}$ & & $\begin{array}{c}0.021 \\
(0.057)\end{array}$ & \\
\hline Donations & $\begin{array}{c}0.420 \\
(0.365)\end{array}$ & $\begin{array}{c}0.259 \\
(0.329)\end{array}$ & $\begin{array}{c}0.040 \\
(0.337)\end{array}$ & $\begin{array}{c}-0.091 \\
(0.317)\end{array}$ & $\begin{array}{c}0.134 \\
(0.096)\end{array}$ & & $\begin{array}{c}0.025 \\
(0.103)\end{array}$ & \\
\hline PAR30 & $\begin{array}{c}-0.019 \\
(1.436)\end{array}$ & $\begin{array}{c}-1.048 \\
(1.674)\end{array}$ & $\begin{array}{c}-0.474 \\
(1.464)\end{array}$ & $\begin{array}{c}-1.290 \\
(1.770)\end{array}$ & $\begin{array}{c}-0.050 \\
(0.293)\end{array}$ & & $\begin{array}{c}-0.041 \\
(0.282)\end{array}$ & \\
\hline WOR & $\begin{array}{c}-4.048 \\
(7.416)\end{array}$ & $\begin{array}{c}-4.082 \\
(6.429)\end{array}$ & $\begin{array}{r}-0.428 \\
(5.984)\end{array}$ & $\begin{array}{c}-1.933 \\
(5.813)\end{array}$ & $\begin{array}{c}-0.786 \\
(1.722)\end{array}$ & & $\begin{array}{c}-0.431 \\
(1.750)\end{array}$ & \\
\hline Rural & $\begin{array}{c}-0.510 \\
(0.591)\end{array}$ & $\begin{array}{c}-0.516 \\
(0.587)\end{array}$ & $\begin{array}{c}-0.464 \\
(0.546)\end{array}$ & $\begin{array}{c}-0.476 \\
(0.544)\end{array}$ & $\begin{array}{c}-0.057 \\
(0.168)\end{array}$ & & $\begin{array}{c}-0.095 \\
(0.172)\end{array}$ & \\
\hline MFI Type & & & & & & & & \\
\hline Credit Union/Cooperative & $\begin{array}{c}0.991 \\
(0.774)\end{array}$ & $\begin{array}{c}0.542 \\
(0.769)\end{array}$ & $\begin{array}{c}0.384 \\
(0.714)\end{array}$ & $\begin{array}{c}0.130 \\
(0.706)\end{array}$ & $\begin{array}{c}0.260 \\
(0.188)\end{array}$ & $\begin{array}{c}0.166 \\
(0.231)\end{array}$ & $\begin{array}{c}0.172 \\
(0.175)\end{array}$ & $\begin{array}{c}0.171 \\
(0.232)\end{array}$ \\
\hline NBFI & $\begin{array}{c}0.380 \\
(0.569)\end{array}$ & $\begin{array}{c}0.218 \\
(0.579)\end{array}$ & $\begin{array}{c}0.226 \\
(0.559)\end{array}$ & $\begin{array}{c}0.096 \\
(0.553)\end{array}$ & $\begin{array}{c}0.097 \\
(0.159)\end{array}$ & $\begin{array}{c}0.242 \\
(0.184)\end{array}$ & $\begin{array}{c}0.065 \\
(0.158)\end{array}$ & $\begin{array}{c}0.249 \\
(0.185)\end{array}$ \\
\hline NGO & $\begin{array}{c}0.181 \\
(0.599)\end{array}$ & $\begin{array}{c}0.190 \\
(0.612)\end{array}$ & $\begin{array}{c}0.299 \\
(0.583)\end{array}$ & $\begin{array}{c}0.322 \\
(0.585)\end{array}$ & $\begin{array}{c}-0.042 \\
(0.182)\end{array}$ & $\begin{array}{l}0.604^{* * *} \\
(0.195)\end{array}$ & $\begin{array}{c}* * 054 \\
\\
(0.195)\end{array}$ & $\begin{array}{c}0.610^{* * *} \\
(0.198)\end{array}$ \\
\hline DOMCRE & & & & & & $\begin{array}{c}-0.003 \\
(0.002)\end{array}$ & & $\begin{array}{c}-0.003 \\
(0.002)\end{array}$ \\
\hline Dispute & & & & & & $\begin{array}{r}-0.265^{*} \\
(0.149)\end{array}$ & & $\begin{array}{r}-0.269^{*} \\
(0.156)\end{array}$ \\
\hline Diamonds & & & & & & & & \\
\hline Low & & & & & & $\begin{array}{c}0.305 \\
(0.188)\end{array}$ & & $\begin{array}{c}0.303 \\
(0.199)\end{array}$ \\
\hline High & & & & & & $\begin{array}{c}0.389^{* *} \\
(0.185) \\
\end{array}$ & & $\begin{array}{c}0.363^{*} \\
(0.191) \\
\end{array}$ \\
\hline Observations & 105 & 105 & 105 & 105 & 105 & 984 & 105 & 984 \\
\hline Pseudo $R^{2}$ & 0.337 & 0.278 & 0.178 & 0.136 & & & & \\
\hline
\end{tabular}

Variables are defined in Table 1.

Standard errors in parentheses: ${ }^{*} p<0.1,{ }^{* *} p<0.05,{ }^{* * *} p<0.01$ 
profit function of an MFI as a theoretical base for the hypothesized statements, we consider the linkage between the social performance of an MFI and its introduction of digital solutions. We also investigate the role of an MFIs profitability, measured by return on equity, in the digitization of the microfinance industry. Additionally, the level of economic development of a specific country can have an influence on the digital transformation of an MFI. The results from the Yapu Solutions survey and the probit regression technique are utilized to test our hypotheses. Our regression results provide no supportive evidence for a mission drift of MFIs which has been the main concern in microfinance research. The major theoretical implication, therefore, is that the digitization process can help to avoid a trade-off between the social and financial performance of the MFIs. In other words, the adoption of digital solutions of MFIs can prevent a distraction of MFIs from their social objectives and a too strong focus on the financial performance. The first effect can be seen through the positive relationship between the adoption of digital tools and the social performance of MFIs. In particular, the number of female borrowers and the real yield on gross loan portfolio manifest a significant correlation with the integration of digital tools. Although our findings regarding the profitability of MFIs support the argument that performing digital solutions is a costly process that poses a need for financial sustainability, it does not appear to foster an increase in the lending rate in order to finance the digital transformation process.

As a practical implication, our findings can be used in the decision-making process of donors, investors, policymakers and other MFI's stakeholders who are concerned about the social impacts of MFIs. To put it differently, these actors could support the digital transformation within the MFIs, especially in social-oriented institutions, if they wish to stimulate social goals such as womens economic empowerment. In addition, these results have implications for a bank's managerial decision with regard to social performance and digital finance. A further practical implication is that supportive policies and regulations which aim at reducing the financial burden of the digital integration process for the MFIs appear to be critical. Subsequently, the MFIs may then have more capacity to expand their digital financial services. Furthermore, our analysis places a new emphasis on the positive relationship between the stage of economic growth and an MFIs engagement in digital solutions. The implementation of digital tools may require a more supportive infrastructure and better legal systems. Practically, this result suggests that it is especially 
promising to boost digital finance in less developed regions.

As our article provides one of the very first insights into the decision of integrating digital solutions into the core business and service delivery of MFIs, we hope that future research will dedicate more efforts to stimulating and supporting the eradication of poverty and financial inclusion through the evolvement of microfinance digitization. To add to this, potential research should employ panel data to account for the continuing impact of digital evolution and the increasing change in the microfinance sector. This will overcome our limitation of cross-sectional data. Since we are only able to consider the influence from the supply-side, the demand-side drivers should also be taken into account, because striving for better outreach to customers remains one of the key pillars in the performance of MFIs.

\section{References}

Abrar, A., Javaid, A. Y., et al., 2016. The impact of capital structure on the profitability of microfinance institutions. South Asian Journal of Management Sciences 10 (1), 21-37.

Ali, W., Frynas, J. G., Mahmood, Z., 2017. Determinants of corporate social responsibility (CSR) disclosure in developed and developing countries: A literature review. Corporate Social Responsibility and Environmental Management 24 (4), 273-294.

Allet, M., Hudon, M., 2015. Green microfinance: Characteristics of microfinance institutions involved in environmental management. Journal of Business Ethics 126 (3), 395-414.

Amersdorffer, F., Buchenrieder, G., Bokusheva, R., Wolz, A., 2015. Efficiency in microfinance: Financial and social performance of agricultural credit cooperatives in Bulgaria. Journal of the Operational Research Society 66 (1), 57-65.

Arun, T., Kamath, R., 2015. Financial inclusion: Policies and practices. IIMB Management Review 27 (4), 267-287.

Ashta, A., 2018. News and trends in Fintech and digital microfinance: Why are European MFIs invisible? FIIB Business Review 7 (4), 232-243. 
Ayayi, A. G., Sene, M., 2010. What drives microfinance institution's financial sustainability. The Journal of Developing Areas, 303-324.

Banerjee, A., Duflo, E., Glennerster, R., Kinnan, C., 2015. The miracle of microfinance? Evidence from a randomized evaluation. American Economic Journal: Applied Economics 7 (1), 22-53.

Beisland, L. A., Djan, K. O., Mersland, R., Randøy, T., 2020. Measuring social performance in social enterprises: A global study of microfinance institutions. Journal of Business Ethics, 1-21.

Benami, E., Carter, M. R., 2021. Can digital technologies reshape rural microfinance? Implications for savings, credit, \& insurance. Applied Economic Perspectives and Policy, 1-25Https://doi.org/10.1002/aepp.13151.

Bhatia, A., Makkar, B., 2019. Csr disclosure in developing and developed countries: A comparative study. Journal of Global Responsibility 11 (1), $1-26$.

Brau, J. C., Woller, G. M., 2004. Microfinance: A comprehensive review of the existing literature. The Journal of Entrepreneurial Finance 9 (1), 1-28.

Brown, M., Guin, B., Kirschenmann, K., 2016. Microfinance banks and financial inclusion. Review of Finance 20 (3), 907-946.

Bruhn, M., Hommes, M., Khanna, M., Singh, S., Sorokina, A., Wimpey, J. S., 2017. MSME finance gap : Assessment of the shortfalls and opportunities in financing micro, small, and medium enterprises in emerging markets. Tech. rep., Washington, D.C.: World Bank Group. URL http://documents.worldbank.org/curated/en/653831510568517947/ MSME-finance-gap-assessment-of-the-shortfalls-and-opportunities-infinancing-micro-small-and-medium-enterprises-in-emerging-markets

Cámara, N., 2018. Digix 2018: A multidimensional index of digitization. BBVA Research.

URL https://www.bbvaresearch.com/wp-content/uploads/2019/04/ Digix_v7-1.pdf

Chakrabarty, S., Bass, A. E., 2015. Comparing virtue, consequentialist, and deontological ethics-based corporate social responsibility: Mitigating microfinance risk in institutional voids. Journal of Business Ethics 126 (3), $487-512$. 
Cull, R., Demirgüç-Kunt, A., Morduch, J., 2018. The microfinance business model: Enduring subsidy and modest profit. The World Bank Economic Review 32 (2), 221-244.

Demirgüç-Kunt, A., Klapper, L., Singer, D., Ansar, S., Hess, J., 2018. The Global Findex Database 2017: Measuring Financial Inclusion and the Fintech Revolution. The World Bank.

D'Espallier, B., Goedecke, J., 2019. Social performance measurement in microfinance. In: A Research Agenda for Financial Inclusion and Microfinance. Edward Elgar Publishing, pp. 62-74.

D’Espallier, B., Goedecke, J., Hudon, M., Mersland, R., 2017. From NGOs to banks: Does institutional transformation alter the business model of microfinance institutions? World Development 89, 19-33.

D'Espallier, B., Guerin, I., Mersland, R., 2013. Focus on women in microfinance institutions. The Journal of Development Studies 49 (5), 589-608.

D'Espallier, B., Hudon, M., Szafarz, A., 2013. Unsubsidized microfinance institutions. Economics Letters 120 (2), 174-176.

Dorfleitner, G., Leidl, M., Priberny, C., von Mosch, J., 2013. What determines microcredit interest rates? Applied Financial Economics 23 (20), $1579-1597$.

Dorfleitner, G., Nguyen, Q. A., Röhe, M., 2019. Microfinance institutions and the provision of mobile financial services: First empirical evidence. Finance Research Letters 31, 357-362.

Dorfleitner, G., Oswald, E.-M., 2016. Repayment behavior in peer-to-peer microfinancing: Empirical evidence from Kiva. Review of Financial Economics 30, 45-59.

Dorfleitner, G., Oswald, E.-M., Röhe, M., 2020. The access of microfinance institutions to financing via the worldwide crowd. The Quarterly Review of Economics and Finance 75, 133-146.

Dorfleitner, G., Priberny, C., Röhe, M., 2017a. Why do microfinance institutions fail socially? A global empirical examination. Finance Research Letters 22, 81-89. 
Dorfleitner, G., Röhe, M., Renier, N., 2017b. The access of microfinance institutions to debt capital: An empirical investigation of microfinance investment vehicles. The Quarterly Review of Economics and Finance 65, $1-15$.

Doumbia, D., 2016. Financial development and economic growth in 43 advanced and developing economies over the period 1975-2009: Evidence of non-linearity. Applied Econometrics and International Development 16 (1), 13-22.

Fu, J., Queralt, J., Romano, M., 2017. Financial inclusion and the 2030 agenda for sustainable development: A missed opportunity. Enterprise Development and Microfinance 28 (3), 200-211.

George, G., Merrill, R. K., Schillebeeckx, S. J., 2020. Digital sustainability and entrepreneurship: How digital innovations are helping tackle climate change and sustainable development. Entrepreneurship Theory and PracticeDOI: $10.1177 / 1042258719899425$.

Ghani, U., Burney, M. T., Ahmad, N., 2018. The impact of technology on the sustainable development of microfinance. Global Sci-Tech 10 (1), 22-29.

Heckman, J. J., Ichimura, H., Todd, P., 1998. Matching as an econometric evaluation estimator. The Review of Economic Studies 65 (2), 261-294.

Hermes, N., Lensink, R., Meesters, A., 2011. Outreach and efficiency of microfinance institutions. World Development 39 (6), 938-948.

Hinson, R., Lensink, R., Mueller, A., 2019. Transforming agribusiness in developing countries: SDGs and the role of FinTech. Current Opinion in Environmental Sustainability 41, 1-9.

Hudon, M., Sandberg, J., 2013. The ethical crisis in microfinance: Issues, findings, and implications. Business Ethics Quarterly 23 (4), 561-589.

Hudon, M., Traca, D., 2011. On the efficiency effects of subsidies in microfinance: An empirical inquiry. World Development 39 (6), 966-973.

Iqbal, S., Nawaz, A., Ehsan, S., 2019. Financial performance and corporate governance in microfinance: Evidence from Asia. Journal of Asian Economics $60,1-13$. 
Ivatury, G., 2009. Using technology to build inclusive financial systems. In: New partnerships for innovation in microfinance. Springer, pp. 140-164.

Jünger, M., Mietzner, M., 2020. Banking goes digital: The adoption of FinTech services by German households. Finance Research Letters 34, 101260.

Kauffman, R. J., Riggins, F. J., 2012. Information and communication technology and the sustainability of microfinance. Electronic Commerce Research and Applications 11 (5), 450-468.

Ketterer, J. A., 2017. Digital finance: New times, new challenges, new opportunities. IDB-Inter American Development Bank.

URL https://publications.iadb.org/publications/english/document/ Digital-Finance-New-Times-New-Challenges-New-Opportunities.pdf

Kim, S. H., Jang, S. Y., Yang, K. H., 2017. Analysis of the determinants of software-as-a-service adoption in small businesses: Risks, benefits, and organizational and environmental factors. Journal of Small Business Management 55 (2), 303-325.

Kriese, M., Abor, J. Y., Agbloyor, E., 2019. Financial access and economic development: The moderating role of financial consumer protection. International Journal of Managerial Finance.

Kumar, K., McKay, C., Rotman, S., 2010. Microfinance and mobile banking: The story so far. Focus Note 62, 1-16.

URL https://citeseerx.ist.psu.edu/viewdoc/download?doi=10.1.1.1023. $3066 \&$ rep $=$ rep1\&type $=$ pdf

Labie, M., Mersland, R., et al., 2011. Corporate governance challenges in microfinance. The Handbook of Microfinance, 283-300.

Lee, C.-C., Li, X., Yu, C.-H., Zhao, J., 2021. Does fintech innovation improve bank efficiency? Evidence from Chinas banking industry. International Review of Economics \& Finance 74, 468-483.

Lee, N., Sameen, H., Cowling, M., 2015. Access to finance for innovative SMEs since the financial crisis. Research Policy 44 (2), 370-380.

Mader, P., 2018. Contesting financial inclusion. Development and Change 49 (2), 461-483. 
Ma'ruf, A., Aryani, F., 2019. Financial inclusion and achievements of sustainable development goals (SDGs) in ASEAN. Journal of Business and Economics Review 4 (4), 147-155.

Mbama, C. I., Ezepue, P. O., 2018. Digital banking, customer experience and bank financial performance. International Journal of Bank Marketing.

McIntosh, C., Wydick, B., 2005. Competition and microfinance. Journal of Development Economics 78 (2), 271-298.

Mersland, R., Strøm, R. Ø., 2009. Performance and governance in microfinance institutions. Journal of Banking \& Finance 33 (4), 662-669.

Mersland, R., Strøm, R. Ø., 2010. Microfinance mission drift? World Development 38 (1), 28-36.

Mersland, R., Strøm, R. Ø., 2012a. Microfinance: Costs, lending rates, and profitability. Handbook of key global financial markets, institutions, and infrastructure, 489-499.

Mersland, R., Strøm, R. Ø., 2012b. What drives the microfinance lending rate? In: Midwest Finance Association 2013 Annual Meeting Paper.

Meyer, J., 2019. Outreach and performance of microfinance institutions: The importance of portfolio yield. Applied Economics 51 (27), 2945-2962.

Mora, T., Prior, F., 2018. The impact of mobile financial services usage on microfinance delinquency. Applied Economics 50 (50), 5354-5365.

Morduch, J., 1999. The microfinance promise. Journal of Economic Literature 37 (4), 1569-1614.

Moro Visconti, R., Quirici, M., 2014. The impact of innovation and technology on microfinance sustainable governance. Corporate Ownership \& Control 11, 420-428.

Mushtaq, R., Bruneau, C., 2019. Microfinance, financial inclusion and ICT: Implications for poverty and inequality. Technology in Society 59, 101-154.

Okoe, A. F., Boateng, H., 2016. Assessing the CSR information needs of microfinance institutions(MFIs) customers. Journal of Information, Communication and Ethics in Society 14 (3), 272-287. 
Parada, M., Bull, G. L., 2018. In the fast lane: Innovations in digital finance. Tech. rep., Washington, D.C. : World Bank Group. URL http://documents.worldbank.org/curated/en/184491531293599982/ In-the-fast-lane-innovations-in-digital-finance

Pazarbasioglu, C., Mora, A. G., Uttamchandani, M., Natarajan, H., Feyen, E., Saal, M., 2020. Digital Financial Services. World Bank Group. URL http://pubdocs.worldbank.org/en/230281588169110691/DigitalFinancial-Services.pdf

Pytkowska, J., Korynski, P., 2017. Digitalizing Microfinance in Europe. Microfinance Centre. URL https://www.europeanmicrofinance.org/sites/default/files/ document/file/Digitalization-research-paper.pdf

Quinones, B., Remenyi, J., 2014. Microfinance and poverty alleviation: Case studies from Asia and the Pacific. Routledge, ISBN: 9781138002135.

Ritchie, H., 2017. Technology adoption. Our World in Data. URL https://ourworldindata.org/technology-adoption

Shaikh, A. A., Glavee-Geo, R., Karjaluoto, H., 2017. Exploring the nexus between financial sector reforms and the emergence of digital banking culture-Evidences from a developing country. Research in International Business and Finance 42, 1030-1039.

Sioson, E. P., Kim, C. J., 2019. Closing the gender gap in financial inclusion through fintech. ADBI Policy Briefs No.2019-3. Asian Development Bank Institute.

Stiglitz, J. E., Weiss, A., 1981. Credit rationing in markets with imperfect information. The American Economic Review 71 (3), 393-410.

Stiglitz, J. E., Weiss, A., 1983. Incentive effects of terminations: Applications to the credit and labor markets. The American Economic Review 73 (5), 912-927.

Tucker, J. W., 2010. Selection bias and econometric remedies in accounting and finance research. Journal of Accounting Literature 29, 31-57. 
UNCDF, 2017. Financial Inclusion.

URL https://www.uncdf.org/financial-inclusion

UNSGSA, 2018. Igniting SDG progress through digital financial inclusion. URL https://sustainabledevelopment.un.org/content/documents/ 2655SDG_Compendium_Digital_Financial_Inclusion_September_2018.pdf

Van Hove, L., Dubus, A., 2019. M-PESA and financial inclusion in Kenya: Of paying comes saving? Sustainability $11(3), 568$.

Vong, J., Song, I., 2015. Lowering the interest burden for microfinance. In: Emerging Technologies for Emerging Markets. Springer, pp. 55-69.

Williamson, O. E., 1979. Transaction-cost economics: The governance of contractual relations. The journal of Law and Economics 22 (2), 233-261.

World Bank, 2018. Financial Inclusion. URL https://www.worldbank.org/en/topic/financialinclusion/overview

Wu, M.-W., Shen, C.-H., 2013. Corporate social responsibility in the banking industry: Motives and financial performance. Journal of Banking \& Finance 37 (9), 3529-3547.

Wyman, O., 2017. Accelerating financial inclusion in South-East Asia with digital finance. Asian Development Bank. URL http://hdl.handle.net/11540/7500

Yeow, A., Chuen, D. L. K., Tan, R., Chia, M., 2017. Indonesian microfinance institutions (MFI) move to technology-TBOP's prodigy experience. In: Handbook of Blockchain, Digital Finance, and Inclusion, Volume 2. Elsevier, pp. 431-449. 


\section{A Rural lending and IT solutions survey}

Here we display those original questions and answer options of the employed questionnaire that are related to the variable Digital solutions.

\section{Digital solutions}

"By digital solutions we mean any software support that contributes to digitalise the processes and/or activities of your financial institution: collection of client's information, credit assessment, credit management, monitoring, reporting, etc. Examples are dedicated software solutions for desktop computers, Apps for tablets or smartphones, etc.

$\cdots$

Does your institution use any digital support solutions for data collection, analysis, reporting on lending activities? (multiple answers are possible)

- No

- Yes, desktop: excel

- Yes, specialized desktop software (not excel)

- Yes, software/App. for tablets or smartphone in the field

- Yes, tablets in the field

- Yes, smart phones in the field

- Other (please specify)" 